\title{
PERAN DAN KENDALA BANK SYARIAH DALAM KONTRIBUSI PENGEMBANGAN UMKM
}

\author{
Slamet Fauzan $^{1}$, Fina Hana Sajidah ${ }^{2}$, Rizky Firmansyah ${ }^{3}$ \\ ${ }^{1}$ Universitas Negeri Malang \\ slamet.fauzan.fe@um.ac.id \\ ${ }^{2}$ Universitas Negeri Malang \\ fina.hana.2004226@students.um.ac.id \\ ${ }^{3}$ Universitas Negeri Malang \\ rizky.firmansyah.fe@um.ac.id
}

\begin{abstract}
Conducting business activities, of course requires funds for the production process. Funds for business activities can be obtained from bank loans, such as Syariah banks. In Indonesia, Islamic banks have an important role in developing the community's economy. The government's hope is that Syariah banks can provide space and convenience for the establishment of businesses carried out by the community. The problem in this article is how the contribution or role of Syariah banking to develop MSMEs, as well as capital constraints faced by Syariah banks and MSME players. This is in accordance with the purpose of writing articles to provide readers with an understanding of the roles and constraints faced by Syariah banking in the development of MSMEs. The method used in writing articles is descriptive approach and literature study. The results of this paper indicate that the role of Syariah banks in developing MSMEs continues to increase but the contribution given is still quite low. Syariah banks only move as a provider of capital only. In writing this article, it can be concluded that the role of Islamic banks in MSMEs currently only focuses on capital so that the contribution made to the national economy is low.
\end{abstract}

Keywords: Syariah Bank; Capital Loan; MSMEs

\begin{abstract}
ABSTRAK
Melakukan kegiatan usaha tentunya memerlukan dana untuk proses produksi. Perolehan dana untuk kegiatan usaha dapat diperoleh dari pinjaman bank, seperti bank syariah. Di Indonesia bank syariah memiliki peranan penting dalam mengembangkan perekonomian masyarakat. Harapan pemerintah yaitu bank syariah dapat memberi ruang dan kemudahan bagi berdirinya usaha yang dilakukan masyarakat. Permasalahan pada artikel ini adalah bagaimana konstribusi atau peran perbankan syariah untuk mengembangkan UMKM, serta kendala permodalan yang dihadapi oleh bank syariah dan pelaku UMKM. Hal ini sesuai dengan tujuan penulisan artikel untuk memberikan pemahaman kepada pembaca mengenai peran dan kendala yang dihadapi perbankan syariah dalam pengembangan UMKM. Metode yang digunakan dalam penulisan artikel yaitu pendekatan deskriptif dan studi literature. Hasil penulisan ini menunjukkan bahwa peran bank syariah dalam pengembangan UMKM terus meningkat tetapi konstribusi yang diberikan masih cukup rendah. Bank syariah hanya bergerak sebagai pihak pemberi modal saja. Dalam penulisan artikel ini dapat disimpulkan bahwa peran bank syariah pada UMKM saat ini hanya berfokus pada permodalan sehingga kontribusi yang diberikan pada perekonomian nasional tergolong rendah.
\end{abstract}

Kata kunci: Bank Syariah; Pinjaman Modal; UMKM 


\section{PENDAHULUAN}

Bank pada hakikatnya merupakan lembaga keuangan penggalangan dan penyalur dana masyarakat. Penyaluran dana yang dilakukan oleh bank pada umumnya digunakan untuk kegiatan usaha, salah satunya adalah UMKM. Usaha Mikro Kecil dan Menengah (UMKM) memegang perkembangan sangat pesat di Indonesia. Intensitas peningkatan pelaku UMKM sangat tinggi. Pelaku usaha UMKM mencangkup beberapa usia, mulai dari orang dewasa hingga para remaja khususnya mahasiswa. UMKM dinilai sangat efektif oleh masyarakat dalam meningkatkan taraf hidup. Saat ini pengetahuan agama dari segala bidang berkembang dengan sangat pesat. Salah satunya yaitu ekonomi dan keuangan syariah. "Ekonomi islam adalah pengetahuan ilmu tentang perilaku manusia dalam mencukupi kebutuhan hidup agar mendapat kedamaian dan kesejahteraan didunia serta diakhirat" (Ascara, 2011). Dalam ekonomi dan keuangan Islam, aturan kegiatan usaha dan bisnis diatur dengan berlandaskan oleh alqur'an dan hadist. Aturan yang berlaku dalam ekonomi dan keuangan Islam mempunyai prinsip menguntungkan semua pihak atau tidak ada pihak yang dirugikan. Perkembangan pola pikir masyarakat untuk membangun UMKM dan ditambah dengan pengetahuan ilmu agama mendorong masyarakat untuk memulai bisnis berlandaskan aturan islam. Minat ini disebabkan tingginya pertumbuhan bank syariah di Indonesia. Tahun 1997 merupakan awal mula lahirnya perokomian berbasis islam melalui lembaga Bank syariah. Dimana pemerintah menjadikan ekonomi islam sebagai salah satu sistem untuk mengembalikan kestabilan perekonomian. Bank syariah memiliki sistem yang relevan yang menguntungkan semua pihak. Penyataan ini sesuai dengan permasalahn krisis ekonomi tahun 1997. Krisis ekonomi yang terjadi membuat hampir semua pelaku usaha mengalami kerugian. Pelaku usaha yang dinilai mampu bertahan adalah UMKM. Untuk mengatasi permasalahan ini, pemerintah menerapkan prinsip bank syariah sehingga krisis ekonomi mulai dapat teratasi.

Bank syariah dikenal sebagai bank tanpa bunga atau lembaga keuangan yang mempunyai sistem operasional berdasarkan alqur'an dan hadist Nabi Muhammas SAW. Bank syariah menawarkan sistem keuangan jauh dari kata riba (bunga atas pinjaman) (Muhammad, 2005). Peluang bank syariah untuk terus berkembang maju sangat 
tinggi di Indonesia. Mengingat mayoritas masyarakat indonesia sebagai muslim tentu akan memberikan dorongan dan dukungan yang besar. Perkembangan ini dapat kita lihat dengan banyaknya intensitas masyarakat untuk menabung dan membuka usaha dengan bank syariah sebagai pemberi modal. Pemberian kredit permodalan yang dilakukan pihak bank, tentunya akan dikenai bunga sebagai imbalan jasa. Umumnya bunga atau imbalan bank konvesional memiliki nilai yang tinggi. Hal ini memunculkan keraguan masyarakat Indonesia mengenai keabsahan bunga pada bank konvensional. Keinginan masyarakat untuk menghindarai bunga atau riba menjadi salah satu alasan bank syariah memiliki perkembangan yang pesat. Serta alasan lain adalah bank syariah dipercaya memiliki banyak keuntungan dan kehalallan yang jelas dimata agama.

Pada masa krisis ekonomi tahun 1997, UMKM dinilai memberikan konstribusi yang penting untuk mempertahankan perekonomian.

Dikarenakan UMKM tidak memiliki banyak ketergantungan terhadap mata uang asing dan bahan produksi impor untuk operasional usaha. Konstribusi UMKM melalui peningkatan PDB nasional bergerak dalam penyerapan tenaga Kerja. Namun, pekembangan UMKM yang ada dalam lapangan, banyak yang memiliki keterbatasan modal. Keterbasan modal yang ada membuat UMKM memiliki dinding penghalang untuk terrus berkembang maju. Dengan adanya lembaga keuangn berbasis syariah diharapkan akan membantu permasalahan yang dihadapi pelaku UMKM.

Fokus utama Usaha perbankan dalam UMKM salah satunya bank syariah yaitu menyalurkan modal kepada pelaku usaha dengan jangkauan yang luas. Tetapi tidak semua kegiatan bank syariah berjalan lancar sesuai rencana. Penyaluran modal ini sering kali mengalami kendala atau hambatan. Terhambatnya penyaluran modal kepada pelaku UMKM mengakibatkan intensitas UMKM menjadi sesak, seperti kesulitan mengembangkan usaha karena tidak mampu memenuhi permintaan dari konsumen yang disebabkan modal kurang. Oleh karena itu, jika hal ini terus terjadi maka tujuan dari bank syariah dalam pengembangan UMKM akan terhalangi. 


\section{TELAAH LITERATUR DAN PENGEMBANGAN HIPOTESIS}

\section{Bank Syariah}

Dalam bahasa prancis, bank adalah bangue dan bahasa italia menyebutnya banco artinya kotak atau kursi. Pernyataan ini menjelaskan arti dari bank yaitu sebagai tempat untuk menghimpun dana dengan aman, serta sebagai penyedia alat pembayaran untuk keperluan jual beli barang maupun jasa. Bank menurut KBBI didefinnisikan sebagai badan keuangan pemberi kredit dan jasa penyimpanan harta masyarakat. Undang-undang no 10 tahun 1998, mendefinisikan bank sebagai badan usaha penghimpun uang atau harta masyarakat berbentuk tabungan yang disalurkan kembali melaui kredit untuk meningkatkan taraf hidup masyarakat. Berdasarkan pengertian tersebut, prioritas kegiatan bank adalah menghimpun dana dalam bentuk tabungan dan mengembangkannya dalam bentuk kredit kepada masyarakat.

Bank syariah adalah lembaga keuangan penampung uang masyarakat untuk disalurkan pada seseorang yang membutuhkan tanpa perinsip bunga, melainkan prinsip syariah (Sjahdeini, 2007). Bank syariah merupakan badan usaha yang melakukan kegiatan operasional berdasarkan prinsip-prinsip syariah islam. Bank syariah adalah bank dengan sistem operasional berlandaskan aturan islam bersumber dari alquran dan hadist, terutama yang menyangkut masalah muamalah ekonomi islam. "Jenis bank syariah di indonesia yaitu Bank Umum Syariah (BUS), Unit Usaha Syariah (BUUS), dan Bank Pembiayaan Rakyat Syariah (BPRS)" (Soemitra, 2009). Peraturan tentang bank syariah di Indonesia diatur dalam undang-undang no 21 tahun 1998 tentang perbankan syariah. Sedangkan pada al-qur'an yaitu surah Annisa ayat 29 dan Al-baqarah ayat 275 yang menjelaskan pelarangan jual beli atau kegiatan usaha yang berhubungan dengan Riba dan tindak kekerasan yang dapat merugikan pihak lain.

Dalam operasional kegiatan bank syariah menghadapi banyak kendala seperti kekurangan modal pendanaan, sumber daya manusia, dan pengetahuan masyarakat yang kurang dengan bank syariah. Kegiatan bank syariah tidak sekuat bank konvesnional yang mengakibatkan minat masyarakat sedikit berkurang. Kendala-kendala ini harus segera diatasi agar bank syariah dapat beroperasional secara maksimal dalam perekonomian Indonesia. 
Prinsip - prinsip Bank Syariah

Prinsip utama bank syariah berlandaskan Al-qur'an dan hadist Nabi Muhammad SAW. Pengakajian lebih dalam ekonomi syariah, menunjukkan sistem operasi bank syariah menjiwai prinsip bertransaksi yaitu efisiensi, keadilan, dan kebersamaan. Prinsip efisien merujuk sikap saling menolong antar sesama secara efektif sehingga mendapatkan manfaat yang besar. Prinsip keadilan mendefinisikan hubungan berdasarkan kejujuran dengan rasa keikhlasan dan persetujuan matang antara kedua belah pihak. Prinsip pebersamaan adalah saling memberikan bantuan dan masukan untuk meningkatkan produktivitas usaha.

Peningkatan produktivitas perbankan syariah indonesia menerapkan 6 pilar kebijakan yang kuat dan efisien seperti struktur perbankan yang sehat, sistem pengaturan efektif, sistem pengawasan indipenden, industri perbankan yang kuat, infrastruktur pendukung yang cukup, dan perlindungan terhadap konsumen (Hariyanto,2017). Arah kebijakan ini sesuai dengan prinsip bank syariah.

Sistem kebijakan bank syariah didasari larangan agama islam untuk mengambil dan meminjamkan dengan bunga sebagai imbalan dari peminjaman atau disebut riba. Prinsip tentu berbeda dengan bank Konvensional yang menerapkan Bunga bank sebagai jasa imbalan. Dalam surah Al-baqarah ayat 276 dijelaskan bahwa Allah tidak menyukai orang yang memakan harta riba, Allah sesungguhnya memusnakan riba dan menyuburkan sedekah serta menghilangkan kefakiran.

Untuk menggantikan riba, sistem bagi hasil diterapkan bank syariah yang sesuai aturan Islam. Dalam pelaksanaanya sistem bagi hasil sering digunakan oleh para pelaku usaha khususnya UMKM. Prinsip dari sistem bagi hasil bank syariah, antara lain :

1. Prinsip Murabahah

Murabahah adalah penjuala barang berdasarkan prinsip keuntungan yang diperoleh penjual. Dalam bank syariah, nasabah akan membeli barang dan membayarkan sesuai dengan kesepakatan. Pembayaran kredit yang dilakuakn memiliki keuntungan yang merupakan harga jual asli barang tersebut (Usmani, 2002).

2. Prinsip Mudharabah

Berupa kerjasama oleh pemilik modal dan pengelola modal dengan keuntungan yang telah ditetapkan pada kesepakatan awal. Pihak bank dalam 
prinsip ini akan menjadi pemilik menerapkan kegiatan berprinsip ekonomi modal dan nasabah akan menjadi dengan karakteristik, antara lain:

pengelola modal. Pada prinsip ini 1. Larangan penerimaan bunga aturan kerugiaan akan ditanggung oleh bank sebagai pemilik modal, namun jika kerugiaan disebabkan pengelola modal maka pengelola modal yang menanggung. riba

2. Tidak mengenal konsep waktu dan uang

3. Uang merupakan fungsi sosial dan jual beli, bukan komoditas

3. Prinsip Musyarakah

Musyarakah adalah kerjasama yang dilakukan dengan modal dan konstribusi kerja secara bersamasama. Pada prinsip Musyarakah keuntungan dan kerugiaan akan ditanggung semua pihak yang terlibat sesuai dengan presentase usaha yang dilakukan.

4. Prinsip Wadiah

Prinsip wadiah adalah Titipan atau tabungan dari nasabah kepada pihak bank. Tabungan ini kemudian dikelola pihak bank sebagai usaha dan membagai hasil dengan nasabah. Nasabah memiliki hak untuk mengambil tabungan sewaktu-waktu.

5. Prinsip Jariyah

Prinsip jariyah adalah prinsip peminjaman dan penitipan didasari dengan tujuan sedekah atau amal jariyah.

Karakteristik adalah cerminan atau identitas suatu kegiatan. Bank syariah

4. Larangan penggunaan 2 harga dalam transaksi bisnis

5. Larangan kegiatan bersifat spekulatif.

\section{Usaha Mikro Kecil dan Menengah}

UMKM atau Usaha Mikro Kecil dan Menengah adalah kegiatan ekonomi usaha bertaraf kecil yang dikelolah masyarakat. Arti UMKM pada undangundang No 20 tahun 1998 adalah usaha kecil dengan jumlah pendapatan terukur, dikelola, dan dimiliki oleh seseorang atau kelompok usaha kecil. Keberadaan UMKM di Indonesia mempunyai keuntungan besar bagi negara seperti terciptanya lowongan kerja, tersedianya barang kebutuhan dan jasa, dan pemerataan usaha meningkatkan pendapatan nasional. Melalui peran tersebut, UMKM memiliki kedudukan yang penting untuk perekonomian nasional (Jaelani, 2015).

\section{Di Indonesia kegiatan UMKM} dinilai sebagai salah satu cara efektif 
mengurangi tingkat kemiskinan. Penyataan ini dapat dilihat dari keberadaan UMKM yang menjadi salah satu sektor usaha terbesar di Indonesia. Terbukti dengan UMKM sebagai wadah pengaman ekonomi dalam menghadapi krisis dan dinamisator pertumbuhan ekonomi pasca kritis.

UMKM memiliki peran penting dalam perekonomian Indonesia. Dari 56 juta total pelaku usaha di indonesia, UMKM memiliki proporsi kontribusi sekitar 99\%. UMKM saat ini mampu menunjukkan citranya pada perekonomian nasional. Terjangan krisis moneter tahun 1998 di Indonesia menunjukkan, bahwa UMKM mampu bertahan secara konsisten dari perusahaan kelas atas. Hal ini dikarenakan, UMKM tidak membutuhkan modal besar dan pinjaman mata uang asing (LPPI: 2015).

Undang - Undang NO 20 tahun

2008 tentang Usaha Mikro Kecil dan Menengah, menjelaskan arti dari macammacam UMKM sebagai berikut:

1. Usaha Mikro merupakan usaha aktif yang dijalankan perorangan dengan kriteria nilai asset maksimal 50 juta dan pendapatan maksimal 300 juta.

2. Usaha Kecil adalah usaha aktif milik peorangan atau badan usaha yang tidak terikat dengan pihak lain seperti perusahaan besar daan menengah, dengan nilai asset 50 sampai 500 juta dan pendapatan 300 juta sampai 2,5 Milliar.

3. Usaha menengah adalah usaha ekonomi yang beridiri sendiri, milik peorangan atau badan usaha yang tidak terikat dengan pihak lain seperti perusahaan besar daan menengah, dengan nilai asset 500 juta hingga 10 milliar dan pendapatan 2,5 milliar sampai 50 milliar.

4. Usaha besar adalah usaha yang dilkelola oleh perusahaan besar dengan kekayaan melebihi usaha menengah, seperti usaha milik negara, perikatan perusahaan dan usaha milik asing di Indoneisa, yang memiliki nilai asset lebih dari 10 milliar dan pendapatan lebih dari 50 milliar pertahun.

Dalam kegiatan bisnis, khususnya UMKM banyak melibatkan pihak bank sebagai pemberi modal. Modal yang berikan akan dikembangkan dalam kegiatan usaha. Tentunya kegiatan usaha dalam UMKM bermacam-macam seperti

1. Usaha Perdagangan

Usaha pada aktivitas jual beli barang mulai dari klontong hingga pengepul. seperti agen rosokan, agen kerudung dan pakaian, toko grosir pasar, dan 
lain-lain. Serta ekspor dan impor beberapa faktor produksi, baik lokal maupun internasional

2. Usaha pertanian

Usaha pada sektor hasil bumi, mulai dari hasil tani dan ebunan seperti kebun apek, kebun jeruk, sayuran, pembibitan benih dan lain-lain. Bahkan termasuk sektor peternakan dan perikanan seperti ternak ayam, pernghasil telur, penghasil susu segar dan tambak ikan.

3. Usaha Industri

Meliputi kegiatan usaha penghasil barang mulai dari barang jadi atau setengah jadi, seperti perusahaan terigu dan gula, perusahaan makanan dan minuman, perusahaan tambang, dan konveksi

4. Usaha Jasa

Meliputi kegiatan yang memberikan pelayanan seperti bengkel, jasa transportasi, jasa telekomunikasi, pelayanan perjalanan dan lain-lain.

Pelaku usaha UMKM pada beberapa sektor tersebut memiliki banyak kendala terutama pada pengetahuan kegiatan pengelolahan usaha. Tidak semua pelaku UMKM berpengetahuan yang cukup matang terutama dalam bidang keuangan. Sosialisasi kegiatan usaha menjadi harapan para pelaku
UMKM untuk dapat mengembangkan usaha. Pelaku UMKM akan mencari pendanaan modal yang sesuai dengan kebutuhan mereka yaitu pada pendanaan modal dan bimbingan kegiatan usaha. pada umumnya bimbingan kegiatan usaha ini mereka dapatkan pada pendanaan bank konvensional dan seminar usaha lembaga pemerintahan.

\section{METODE PENELITIAN}

Penulisan artikel ini menggunakan pendekatan deskriptif, studi literatur, dan penelitian referensi. Pendekatan deskriptif merupakan pendekan pada metode penulisan untuk menggambarkan keadaan sosial untuk mengeksplorasi dan klarifikasi mengenai suatu fenomena pada kenyataan sosial. Studi literatur adalah penulisan yang dilakukan dengan cara meneliti berbagai jurnal dan tulisan dari sumber baca yang relevan.Sumber penulisan diambil dari jurnal dan artikel serta e-book terkait teori dari permasalahan yang dibahas.

Penelitian yang menggunakan berbagai sumber karya tulis untuk memperoleh data dalam pengembangan argumentasi merupakan pengertian referensi menurut Sutama. Sumber karya tulis atau referensi berasal dari jurnal yang 
relevan, dimana data yang terdapat dalam jurnal juga berasal dari sumber relevan yang telah diakui. Dalam penulisan karya ilmiah ini metode yang digunakan betujuan untuk memaparkan peran dan kendala yang dihadapi bank syariah dalam pengembangan UMKM. Melalui data yang diperoleh, data dikembangkan kembali dan dikaji untuk dijadikan sebuah artikel ilmiah yang sesuai tujuan.

Jenis sumber data penulisan artikel dibagi menjadi dua yaitu primer dan sekunder. Sumber primer berasal dari pihak pertama secara langsung. Sumber primer pada penulisan artikel diperoleh melalui wawancara pihak terkait. Sedangkan, sumber sekunder berasal dari data-data dan file dari institusi atau lembaga yang telah melakukan publikasi data pada masyarakat terhadap pengumpulan data yang telah dilakukan. Pada penulisan artikel ini, sumber data digunakan adalah sumber data sekunder. Sumber data yang didapatkan berasal dari berbagai jurnal dan artikel tentang perbankkan syariah dan pengembangan UMKM yang telah dirilis diwebsite yang relevan.

Secara umum jenis data penelitian dibedakan menjadi dua yaitu kualitatif dan kuantitatif. Jenis data kualitatif berasal dari penelitian objek, observasi, dan wawancara narasumber. Sedangkan jenis data kuantitatif merupakan penulisan artikel dengan melakukan pengembangan terhadap angka - angka hasil observasi dan kegiatan. Jenis data yang digunakan dalam penulisan artikel adalah jenis data kualitatif. Data yang digunakan meliputi artikel dan jurnal tentang perbankan syariah dan pengembangan UMKM. Selain itu, literatur lain berasal dari hasil penulisan dari pihak-pihak sebelumnya yang telah mempublikasikan beberapa permasalahan yang sesuai.

\section{HASIL PENELITIAN DAN PEMBAHASAN}

\section{Pemberdayaan UMKM}

Pemberdayaan dalam KBBI berarti kemampuan dalam bertindak. Arti lain pemberdayaan adalah kekuatan dan daya tahan. Secara teknis permberdayaan sama dengan pengembangan. Pemberdayaan adalah mengembangkan kemampuan (daya) dan potensi yang ada dalam diri manusia. Pemberdayaan dapat dikatakan sebagai upaya memenuhi kebutuhan individu, kelompok, dan masyarakat luas untuk mengendalikan pergerakan lingkungan sosial termasuk kegiatan aksebilitas dan lain-lain. 
Pemberdayaan UMKM dilakukan pemerintah untuk mengatasi masalah kemiskinan. Dengan pengelolahan aturan kegiatan UMKM pada masyarakat. Adanya UMKM memberikan ruang untuk menyerap tenaga kerja pada masyarakat. Penyerapan tenaga kerja pada sektor UMKM hampir 99,45\% total tenaga kerja di Indonesia. Tetapi PDB yang diperoleh pemrintah masih tergolong rendah sekitar $30 \%$. Oleh karena itu pemberdayaan UMKM untuk mendorong kemajuan dan kesejahteraan masyarakat perlu dikembangkan. Pengembangan UMKM tentunya akan membuat usaha yang dijalankan menjadi lebih prospektif dan laba yang dihasilkan akan besar. Hal ini, akan mendorong adanya lowongan kerja sehingga pengangguran yang ada dapat diserap dengan baik (Supriyanto, 2006).

Pertumbuhan dan peran UMKM dalam perekonomian Indonesia diperkirakan akan terus mengalami peningkatan, yang disebabkan iklim investasi dan usaha telah ditangani oleh pemerintah secara bertahap, sehingga faktor dan kendala terburuk akan sulit untuk berkembang [Fatimah, 2011].

\section{Peran Bank syariah dalam}

\section{pengembangan UMKM}

Peran penting untuk meningkatkan eksistensi pertumbuhan dikaca internasional oleh UMKM perlu dikembangkan. Pengembangan UMKM semakin tinggi akan mendorong kesejahteraan masyarakat meningkat yang membawa keuntungan terhadap pemerintah. Keuntungan yang diperoleh pemerintah terhadap UMKM di Indonesia yaitu teratasinya masalah pengangguran. UMKM akan menyerap tenaga kerja yang ada pada masyarakat. Sehingga secara tidak langsung akan memberikan sumbangan GDP yang besar bagi pemerintah. Oleh karena itu, suatu kewajiban bagi pemerintah dan pihak terkait khusunya lembaga keuangan untuk menjadi garda terdepan yang mendorong pengembangan UMKM pada masyarakat.

Dalam pengembangan UMKM, bank menjadi lembaga keungan dengan kronstribusi yang sangat penting, mulai dari dank konvesional hingga syariah. Sistem operasional yang berlaku dikedua bank ini memiliki perbedaan yang besar. Dimana pada bank syraiah tidak menerapkan prinsip bunga sebagai imbalan jasa. Pada bank syariah aturan yang dibuat sesuai dengan syariah islam berdasarkan peraturan al-qur'an dan 
hadist. Intensitas ketertarikan masyarakat pada perbankan syariah semakin tinggi dari waktu kewaktu. Hal ini didasari dengan perkembangan ilmu agama muamalat (ekonomi keuangan) yang semakin pesat pada teknologi informasi.

Intensitas ketertarikan masyarakat mendorong peran bank syariah pada perokonomian semakin meningkat. Terbukti dengan adanya lembaga bank syariah yang semakin banya seiring berjalannya waktu. Bank syariah dalam masyarakat menjadi lembag penghimpun dana (tabungan) dan lembaga peminjaman yang berlandaskan prinsip bagi hasil. Prinsip bagi hasil kerap dimanfaatkan oleh masyarakat khusunya pelaku UMKM yang bertujuan memperoleh keuntungan atas ridho Allah SWT.

Peran bank syariah dalam pengembangan UMKM sebagai pemodal atau penyalur dana pada masyarakat. Dengan dukungan dari pemerintah, Edy Setyadi selaku Direktorat Perbankan syariah Bank Indonesia menjelaskan fokus lembaga bank syariah saat ini adalah membantu pemberdayaan UMKM pada pemodalan seluas-luasnya, untuk mendorong kesejahteraan rakyat. Perbankan syariah mengatakan bahwa sektor usaha terbesar di Indonesia adalah UMKM, yang berjumlah 52 juta UMKM aktif dan 9\% diantaranya pada sektor Usaha Mikro.

Pendanaan modal usaha yang dilakukan perbankan syariah dilakukan melalui 2 cara yaitu langsung dan bertahap. Permodalan langsung dilakukan tanpa perantara pihak lain atau langsung pada pelaku UMKM. Sedangkan permodalan bertahap disalurkan melalui lembaga terkait yang telah bekerjasama dengan bank syariah dalam memperluas cangkupan nasabah. Permodalan bertahap dilakukan melalui lembaga kemitraan bank syariah seperti BMT. Dengan BMT (Baitul Mal wa Tamwil), bank syariah bekerja sama menyalurkan modal pada masyarakat dimana BMT menjadi mitra bisnis dan debitur bank syariah. BMT adalah lemabaga keuangan penyalur dana bukan bank yang bergeraki pada sistem syariah islam dengan prinsip bagi hasil. (Azra, 2003)

Bank syariah memiliki sistem pengoperasian yang berbeda, tergantung fokus tujuan dari usahanya. Salah satu contoh perngoperasian bank syariah adalah mendirikan pusat permodalan sektor usaha Mikro seperti gerai dan sentra UMKM. Sebagai upaya pemerataan permodalan, Bank syariah dengan jangkauan yang besar akan menyalurkan dana kepada bank syariah kecil seperti 
BPRS dan BMT. Lembaga bank syariah kecil ini mudah ditemui didaerah-daerah yang cukup jauh dari perkotaan. Pemerataan pembangunan lembaga bank syariah ini ditujukan untuk memaksimalkan peran bank syariah dalam permodalan UMKM.

Guna

meningkatkan

pengembangan UMKM, bank syariah menerapkan prinsip untuk permodalan pelaku UMKM. Perinsip utama yang dipakai dalam pengembangan UMKM adalah prinsip Musdharabah dan Musyarakah. Prinsip Mudharabah merupakan aturan kerja sama usaha, dengan keuntungan bagi hasil, oleh bank (pemberi moda) dan pelaku usaha (pengelola). Keuntungan yang didapat akan dibagi berdasarkan kesepakatan yang ditentukan. Prinsip Musyarakah adalah prinsip kerja sama usaha, dimana bank dan pelaku usaha bertindak sebagai pemodal dan pengelola. Prinsip musyarakah memiliki kelebihan dimana kerugian yang terjadi akan ditanggung kedua pihak.

\section{Berdasarkan prinsip yang} dijalankan, dapat disimpulkan bahwa bank syariah memiliki potensi yang tinggi untuk membantu kemajuan ekonomi dan industri terutama pada sektor UMKM. Permodalan yang diberikan oleh bank syariah dinilai akan memberikan keuntungan yang merata dan jauh dari kerugian. Peran bank syariah dalam permodalan juga dapat diterapkan oleh semua kalangan atau agama, dikarenakan sifatnya yang fleksibel.

Prinsip bagi hasil mudharabah dan musyarakah berfokus pada untung rugi bagi nasabah. Besar nilai bagi hasil yang disalurkan kepada bank tergantung keuntungan akhir yang didapat oleh nasabah (pengelola). Sehingga prinsip mudharabah dan musyarakah dinilai cocok dalam memberikan modal bagi sektor usaha UMKM yang tidak akan merasa terbebani.

\section{Peran Bank Syariah Dalam}

\section{Pembiayaan Linkage Program}

\section{Pengembangan UMKM}

Pembiayaan melalui linkage program saat ini menjadi salah satu peran bank syariah pada UMKM. Linkage program adalah pembiayan yang dilakukan oleh bank syariah pada pelaku UMKM melalui kemitraan. Pembiayaan linkage program sering dilakukan dengan pelaku usaha mikro. Pemberian biaya bank syariah dilakukan melalui lembaga kemitraanya seperti BPRS (Bank Perkreditan Rakyat Syariah), LKMS (Lembaga Keuangan Mikro Syariah) 
contohnya KJKS (Koperasi Jasa Keuangan Syariah) dan BMT (Baitul Mal Wat Tamil). Dalam ekonomi islam sebenarnya tidak mengenal Linkage program. Namun dilihat dari pelaksanaannya untuk mencapi tujuan secara sharing resource, maka dinilai sama dengan program ukhuwah islam yaitu persaudaraan (Bank Indonesia,2004). Beberapa metode yang diterapkan dalam linkage program adalah executing, chenneling dan joint financing.

Metode executing adalah pola pembiayaan yang dilakukan bank syariah kepada LKMS yang kemudian disalurkan kepada pelaku mikro sebagai penerima modal. Pada metode ini LKMS berperan sebagai pihak yang memtuskan nasabah pelaku mikro untuk menerima pengkreditan modal. Pada pembiayaanya LKMS dikenal sebagai debitur bank syariah, sedangkan pelaku usaha mikro sebagai eksposur. Pada pola ini kegagalan permodalan bisnis yang mengakibatkan kerugian akan ditanggung oleh LKMS. Pada prinsip pelaksanaan, bank syariah dengan LKMS menggunkan prinsip Mudharabah. Sedangkan LKMS dengan pelaku mikro prinsip yang digunakan menyesuaikan kesepakatan kedua pihak.
Metode chenneling adalah pembiayaan bank syariah kepada pelaku UKM secara langsungsebagai end user dan LKMS bertindak sebagai wali dari pelaku UKM. LKMS tidak berhak untuk memutuskan nasabah penerima kredit modal. Dalam metode ini kerugian bisnis secara normal akan ditanggung oleh bank syariah dan pelaksanaan akan yang dilakukan oleh UKM dengan Bank syariah adalah prinsip wakalah.

Metode joint financing adalah pembiayaan modal kepada UMK yang dilakukan oleh Bank syariah dan LKMS pada pembiayaan dana. Pada metode ini pembiayaan dana berasal dari bank syariah dan LKMS, begitupun dengan risiko kerugian yang terjadi akan ditanggung oleh kedua pihak secara bersama-sama. Prinsip akad metode joint financing adalah prinsip musyarakah.

Penerapan metode linkage merupakan salah satu peran bank syariah dalam pemerataan permodalan kredit bagi pelaku UMKM. Peran bank syariah pada metode Linkage bertindak sebagai ibu kreditur atau pembiayaan utama. Saat ini pembiayaan linkage program menjadi unggulan pada bank syariah. 


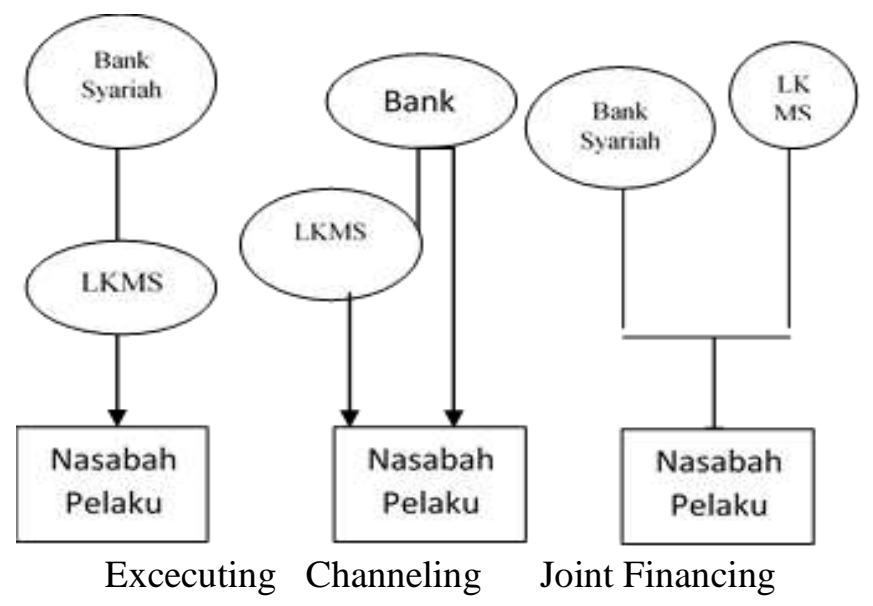

Gambar 1. Model - model pembiayaan Linkage program

\section{Penyaluran Modal Keuangan Bank}

\section{syariah Pada Pelaku UMKM}

Menurut (M. Capra, 2000) sistem perbankan islam bergerak sebagai tonggak pendukung tujuan pemberdayaan kesejahteraan sosial dan ekonomi syariah. Mekanisme penyaluran dana kepada pelaku UMKM, antara lain:

1. Membuat produk pelayanan usaha mikro seperti gerai dan sentra UMKM.

2. Pembiayaan usaha mikro dengan sistem bagi hasil.

3. Konsisten menurunkan tim marketing untuk menjangkau seluruh pelaku UMKM.

4. Sosialisasi kepada pelaku UMKM tentang strategi kegiatan bisnis dan pembantuan modal.

5. Layanan tabungan yang berdasarkan keuntungan bagi hasil dengan bank syariah.
Syarat-syarat yang harus dipenuhi oleh pelau UMKM untuk mendapatkan bantuan modal, antara lain: Warga negara Indonesia, Memiliki usaha baik perorangan maupun badan usaha, Mempunyai SKU (surat keterangan usaha) serta memiliki jaminan.

Penyaluran dana UMKM dapat diperoleh oleh semua pihak yang memenuhi persyaratan diatas. Pelaku usaha akan mendatangi lembaga bank syariah untuk mengajukan bantuan permodalan. Salah satunya dengan menjadi nasabah dalam bank syariah tersebut. Pengurusan bantuan UMKM akan dibimbing langsung oleh pihak bank syariah. Sebelum pemberian dana pihak bank syariah akan mendatangi tempat pelaku melakukan kegiatan UMKM untuk menentukan jumlah dana yang diterima pelaku usaha tersebut. 
Kendala Bank syariah dalam

\section{Pengembangan UMKM}

Bank syariah memiliki kendala yang harus dihadapi dalam pengembangan UMKM. Meskipun memiliki banyak keunggulan, peran bank syariah dalam perekonomian dinilai memiliki presentasi yang kurang besar bagi pemerintah. Minat masyarakat yang terus meningkat pada bank syariah masih belum mendorong eksistensi bank syariah dalam perekonomian nasional. Perlu diketahui, faktanya konstribusi bank syariah dalam perekonomian nasional hanya $0,23 \%$. Untuk membantu perokomian khsususnya inflasi guna mendorong pengembangan UMKM secara maksimal, bank syariah harus memiliki peran 10\%-20\% dalam perekonomian.

Bank syariah memiliki kendala dalam pengembangan UMKM. Kendalakendala yang dihadapi antara lain:

1. Sulitnya menghimpun dana permodalan. Meskipun intensitas ketertarikan masyarakat tinggi, tetapi permodalan yang dimiliki bank syariah dinilai kurang.

2. Kurangnya Sumber Daya Manusia yang berkualitas. Dalam menjalankan ekonomi berbasis syariah tentulah harus memiliki pengetahuan ekonomi islam mu'amalat. Fakta dilapangan menunjukkan SDM dengan kemampuan keuangan islam kurang berkembang.

3. Kebijakan pemerintah yang terbilang lamban. Pemberdayaan pemerintah pada sektor UMKM bank syariah terbilang lamban, tidak seefektif dan sebesar bank konvensional. Hal ini dikarenkan sistem bank syariah yang berkembang di Indonesia terbilang baru.

4. Kegiatan bank syariah yang belum tuntas. Bank syariah pada umumnya hanya berkonstribusi kepada pemberian dana bagi pelaku UMKM. Namun, untuk pembantuan pengelolahan dan informasi usaha kurang diterapkan.

5. Kurangnya sosialisasi lapisan kepada masyarkat bawah. Kebanyakan pelaku UMKM yang memilih bank syariah sebagai pemodal adalah kelas menengah. Masyarakat kelas bawah khususnya pelaku ekonomi mikron kurang mengetahui efisiensi dari bank syariah. Mereka cenderung lebih percaya pada bank konvensional.

6. Bank syariah memiliki system perhitungan yang rumit untuk sebgian masyrakat. Pada sistem bank syariah pengembalian dana yang dilakukan pelaku UMKM setiap bulan 
berdasarkan bagi hasil keuntungan usaha yang mereka peroleh. Banyak pelaku UMKM khususnya pelaku mikro memiliki pengetahuan kurang dalam perhitungan keuangan, yang mengakibatkan mereka enggan untuk mengajukan pinjamna modal pada bank syariah.

7. Pembangun lembaga bank syariah dinilai kurang merata. Saat ini pembangunan lembaga bank syariah sedang dikejar. Namun, waktu yang diperlukan menghambat pemerataan bank syariah. Daerah yang telah memiliki lembaga bank syariah kecil umumnnya daerah dengan kabupaten atau kota terkenal. Kushusnya wilayah jawa.

8. Persaingan bank konvesional dan syariah. Eksistensi bank konvensional saat ini telah menawarkan bunga pinjaman UMKM yang sangat kecil, sekitar 2,5\% - 5\%. Hal ini membuat masyarakat lebih memilih bank konvesional, terutama telah memiliki nama yang besar

\section{Kendala UMKM Dalam Perolehan}

Modal dan Pembagian Hasil Dengan

Bank syariah

Kendala dalam permodalan UMKM juga dimiliki oleh pelaku UMKM sendiri. Ketidak tersediaan jaminan yang cukup oleh sebagian besar pelaku UMKM, Menjadi salah satu hambatan untuk memperoleh pembiayaan modal. Sebagian besar bank baik konvensional maupun bank syariah memberikan kebijakan penyediaan jaminan untuk memperoleh pengkreditan modal. Jaminan ini berfungsi sebagai bentuk pengamanan yang dilakukan oleh pihak bank, jika suatu saat terjadi permasalahan pada kegiatan UMKM.

Pada bank syariah kendala yang dihadapi oleh UMKM selain permodalan adalah penghitungan administrasi keuangan. Keterbatasan pengetahuan keuangan pelaku UMKM khususnya mikro, mengakibatkan mereka enggan untuk mengajukan kredit permodalan pada bank syariah. Setiap bulan mereka diharuskan untuk menghitung laba bersih yang didapatkan dan melakukan perhitungan bagi hasil. Hal ini dirasa rumit dan membingungkan karena harus dilakukan setiap bulan.

Selain itu, harga produk bank syariah sebagian besar lebih tinggi dari bank konvensional yang mempengaruhi minat masyarakat dalam melakukan hubungan usaha dengan bank syariah. Meskipun peminat bank syariah saat ini terus bertambah, tetapi jumlah nasabah 
yang ada tidak sebesar bank konvensional.

Kekurangan nasabah inilah yang sebenarnya menjadi penyebab utama tingginya harga produk pada bank syariah. Pelaku UMKM yang memiliki pendapat realtif rendah, mengaku keberatan pada beberapa produk bank syariah.

\section{Solusi Pengembangan Peran Pihak-}

\section{Pihak Terkait UMKM}

Pihak-pihak terkait UMKM sangat beragam bukan hanya bank seperti bank syariah dan konvesional, dan pelaku UMKM. Kegiatan usaha di Indonesia juga memiliki sitem perpajakan sebagai dana pendapatan pemerintah yang nantinya masuk GDP. Dana pajak ini diambil untuk membantu pengembangan UMKM di Indonesia.

Namun, peran yang dilakukan oleh pihak-pihak UMKM masih kurang maksimal, sehingga diperlukan perngembangan konstribusi pihak-pihak terkait, seperti:

\section{Bank syariah}

Peran yang harus ditingkatkan bank syariah, antara lain :

a. Mengoptimalkan fungsi sosial yaitu penyaluran dana kepada pelaku UMKM secara maksimal. b. Meningkatkan pelayanan keuangan mikro khususnya UMKM.

c. Membantu pemberian bimbingan bagi pelaku UMKM, mengenai tatacara kegiatan khusunya pengelolahan keuangan.

d. Meningkatkan penyuluhan keuangan yang berbasis syariah islam dengan tujuan kesejahteraan dunia dan akhirat.

2. Direktorat Jenderal Pajak (DJP)

Direktorat jenderal pajak adalah lembaga pengawasan pajak yang ada di Indonesia mulai dari pajak Usaha, Penghasilan, hingga bumi bangunan. Peran DJP dalam UMKM antara lain:

a. Memberikan penyulahan serta edukasi kegiatan UMKM.

b. Jika memungkinkan, ikut memberikan bantuan pendanaan lewat lembaga keuangan UMKM.

c. Memaksimalkan peran akun respresentative dalam pengembangan UMKM.

3. Kementrian / dinas

Kementrian / dinas merupakan wadah dari kegiatan UMKM, peran yang harus ditingkatkan antara lain :

a. Memberikan edukasi kegiatan UMKM dan pemberian dana yang mencukupi. 
b. Memberikan edukasi sistem Peranan penting dalam akutansi dan keuangan bisnis pada pengembangan UMKM, pada dasarnya UMKM.

\section{Pelaku UMKM}

Peranan penting yang harus ditingkatkan UMKM dalam mengembangkan usahanya, antara lain:

a. Meningkatkan pengetahuan akutansi dan pengembangan bisnis, dengan mengikuti seminar kegiatan UMKM.

b. Mengupayakan penerapan pecatatan menggunakan sistem akutansi yang baik dan benar, meskipun dalam bentuk paling sederhana.

c. Mengambil keputusan bisnis secara relevan berdasarkan data usaha yang ada.

5. Akademisi / konsultan

Akademisi atau konsultan sering kali kurang diketahui oleh masyarakat. Peran yang harus ditingkatkan akademisi antara lain :

a. Aktif dalam peran menjadi narasumber pada kegiatan UMKM.

b. Menjalin kerja sama yang luas dengan pihak lain, terkait penggalaan edukasi kegiatan UMKM. bukan hanya dilakukan oleh pihak utama saja seperti pelaku UMKM sendiri dan bank syarriah. Tetapi semua pihak terkait UMKM harus saling bekerja sama memberikan kinerja yang maksimal. Ketika semua peran dijalankan dengan baik maka permasalahan dan kendala yang dihadapi dalam UMKM akan segera teratasi.

\section{KESIMPULAN}

Peran bank syariah di Indonesia dalam kontribusi pengembangan UMKM satat ini kurang maksimal. Dalam peran perekonomian nasional, bank syariah hanya berkonstribusi $0,23 \%$ dari nilai konstribusi minimal $10 \%$ untuk mengentas masalah perkonomian secara keseluruhan. Konstribusi yang dilakukan oleh bank syariah hanya berfokus pada pemodalan dan usaha kepada pelaku UMKM. Kurangnya konstribusi bank syariah pada kegiatan pemberian informasi usaha menjadikan minat masyarakat berkurang untuk menjadi nasabah bank syariah. Terdapatnya kendala - kendala yang dihadapi oleh bank syariah dan pelaku UMKM mengakibatkan lemahnya tingkat kegiatan 
pada bank syariah. Untuk mengatasi permasalahan yang ada bank syariah menerapkan beberapa program seperti program Linkage. Program linkage bertujuan meratakan permodalan bank syariah pada pelaku UMKM dengan melibatkan lembaga kemitraan.

Bank syariah menggunakan prinsip ekonomi islam dalam melakukan hubungan bisnis dengan nasabahnya. Prinsip ekonomi islam yang digunakan adalah bagi hasil dimana prinsip ini menguntungkan semua pihak. Prinsip bagi hasil yang digunakan pada permodalan kredit pelaku UMKM adalah prinsip musharabah, musyarakah, dan wakalah. Ketiga prinsip ini dikembangkan oleh bank syariah melalui program Linkage bersama kemitraannya seperti BPRS, LKMS, dan BMT. Dengan adanya kemitraan pada pengembangan UMKM melalui bank syariah, menjadikan nasabah lebih merasa aman dan terpercaya. Dikarenakan saat ini, bank syariah masih tertinggal jauh dalam eksistensi melawan bank konvensional. Pengembangan UMKM melalui lembaga bank syariah memerlukan konstribusi pihak lain terkait UMKM seperti OJK, Kementrian / Dinas dan konsultan. Peran penting pihak terkait akan mengakibatkan keselarasan kegiatan usaha jika berjalan secara beriringan. Hal ini dikarenkan peraturan pada bank syariah juga memerhatikan aturan yang dikeluarkan oleh pemerintah selaku tonggak utama perekonomian.

Kendala dalam penelitian ini adalah kajian literatur yang masih kurang. Harapannya untuk peneliti selanjutnya dapat menggunakan pendekatan penelitian yang berbeda dan dapat menambah kajian literaturnya.

\section{DAFTAR PUSTAKA}

Ascara. (2011). Akad Dan Produk Bank Syariah. Jakarta: Raja Grafindo Persada.

Azra, A. (2003). Bederma Untuk Semua. Jakarta: PT. Mizan Publika.

Bank, I. (2004). Linkage Antar LKS. Jakarta: Bank Indonesia.

Fatimah, T. (2011). Strategi Pemberdayaan Usaha Mikro Kecil Dan Menengah (UMKM) Dalam Menghadapi Globalisasi. Jurnal Econosains , 52.

Ascara. (2011). Akad Dan Produk Bank Syariah. Jakarta: Raja Grafindo Persada.

Azra, A. (2003). Bederma Untuk Semua. Jakarta: PT.Mizan Publika.

Bank, I. (2004). Linkage Antar LKS. Jakarta: Bank Indonesia.

Fatimah, T. (2011). Strategi Pemberdayaan Usaha Mikro Kecil Dan Menengah (UMKM) Dalam 
Menghadapi Globalisasi. Jurnal Econosains, 52.

Hariyanto, P. (2017). Peran Bank Syariah Dalam Mengupayakan Solusi Permasalahan Akutansi Pada Usaha Mikro, Kecil, Dan Menengah. Justicia Islamica, 6070.

Ibrahim, K. (2014). Penerapan Prinsip Mudharabah Dalam Perbankan Syariah. Jurnal IUS, Vol 2, No 4, 42-53.

Jaelani, A. (2015). Analisis Terhadap Mekanisme Pembiayaan Mikro Dengan Akad Murabahah Di Bank Syariah Mandiri Kantor Cabang Pembantu Semarang Timur. Journal Skripsi, 23-24.

Kara, M. (2013). Konstribusi Pembiayaan Perbankan Syariah Terhadap Pengembangan Usaha Mikro, Kecil, Dan Menengah. Jurnal AlHakam, 315-322.

Lembaga Pengembangan Perbankan Indonesia (LPPI), B. I. (2015). Profil Bisnis Usaha Mikro, Kecil Dan Menengah (UMKM).

Lina Marlina, B. Z. (2018). Peran Lembaga Keuangan Syariah Dalammengimplementasikan Keuangan Inklusif Bagi Pelaku UMKM Tasikmalaya. Jurnal Ecodemica, Vol. 2, 2-12.

M. Capra, U. (2000). Sistem Moneter Islam. Ekonomi Islam, 225-240.

Maryati, S. (Vol. 3 No.1 ). Peran Bank Pembiayaan Rakyat Syariah Dalam Pengembangan UMKM
Dan Agribisnis Pedesaan Di Sumatera Barat . Journal of Economic And Economic Education, 1-17.

Muhammad. (2005). Manajemen Dana Bank Syariah. Yogyakarta: Ekonisia.

Sjahdeini, S. R. (2007). Perbankan Islam. Jakarta: PT Pustaka Utama Grafiti.

Soemitra, A. (2009). Bank Dan Lembaga Keuangan Syariah. Jakarta: Kencana.

Supriyanto. (2006). Pemberdayaan Usaha Mikro Kecil Dan Menengah (UMKM) Sebagai Salah Satu Upaya Penanggulangan Kemiskinan. Jurnal Ekonomi Dan Pendidikan, 10.

Tripalupi, Ramadhani Irma (2017). Linkage Program Dan Pasar Modal Sebagai Alternatif Dalam Akses Pendanaan Umkm Di Era Masyarakat Ekonomi ASEAN (MEA). Journal 'Adliya Vol. 11, No. 2.

Usmani, T. (2002). An Introduction To Islamic Finance. Makataba Ma'arif Quran Karachi.

Wanita, N. (2015). Perkembangan Usaha Mikro Kecil Dan Menengah (UMKM) Dipasar Manonda Palu. Jurnal Penelitian Ilmiah, Vol. 3 No. 2.

Zamroni. (2013). Peran Bank Syariah Dalam Penyaluran Dana Bagi Usaha Mikro, Kecil, Dan Menengah (UMKM).Journal Iqtishadia, Vol. 6, 225-240. 